https://doi.org/10.31470/2706-7904-2020-15-226-229

\title{
ДИСКУРС ВОЛОНТЕРСЬКОГО РУХУ В СВІТІ СУЧАСНИХ ЛІНГВІСТИЧНИХ ДОСЛІДЖЕНЬ
}

\section{Volunteer Discourse in Modern Linguistic Researches}

\section{Larysa Snihur}

\author{
Ph.D. Student \\ National Academy of Security Service of Ukraine \\ larisa.snigur7@gmail.com \\ https://orcid.org/0000-0001-8412-3734
}

\begin{abstract}
The abstract reveals the problem of volunteer discourse as a type of institutional discourse which is realized the specific sphere of social interaction and is an integral part of the modern society. General characteristics of the volunteer discourse as a complex cognitive sociolinguistic phenomenon are presented.
\end{abstract}

Key words: discourse, volunteer discourse, institutional discourse.

\section{Вступ \\ Introduction}

Антропоцентризм, притаманний сучасним лінгвістичним дослідженням, визначає підвищений інтерес дослідників до ролі людського (соціокультурного, психологічного, суб'єктивного, модального) чинника в комунікативних процесах, вивчення якого займає все більш вагоме місце в роботах з мовознавства. В результаті, у світовій лінгвістиці складається і зміцнює свої позиції нова інтегрована когнітивнодискурсивна парадигма, ключовим поняттям якої стає «дискурс». У руслі цієї парадигми, в якій мова розглядається як цілеспрямована діяльність, що виконує роль «посередника» в динамічному процесі людського спілкування, дискурс, що представляє собою ланку між людською комунікацією і всієї сукупністю ознак, що впливають на неї - прагматичних, соціокультурних, психологічних, економічних та інших, закономірно виступає на перший план у лінгвістичних дослідженнях. На сучасному етапі з'являється все більше робіт, присвячених виділенню і опису особливостей різних видів дискурсів, наприклад, рекламного (Медведева, 2003) 
політичного (Белова, 1997; Chouliaraki, 2000), аргументативного (Белова, 1997), публіцистичного (Чернишева, 2003) та ін. Проте лінгвістичні джерела (Арутюнова, 1998; Бацевич, 2004; Дейк ван, 2001; Карасик, 1999; Кубрякова, 1997; Рогожнікова, 2002; Селіванова, 2002; Серіо, 1999; Серажим, 2002; Скуратовська, 2002 та ін.) вказують на неоднозначність трактування та багатовекторність підходів до вивчення цього понятт: формальний, комунікативний, прагматичний, когнітивнопрагматичний, семіотичній тощо. Проте, незважаючи на певні напрацювання в галузі дослідження дискурсу, зокрема дискурсу, пов’язаного з феноменом волонтерства, низка проблем залишається недостатньо вивченою. Тому питання дослідження загальних і специфічних рис реалізації лінгвокультурних особливостей дискурсу волонтерського руху потребує комплексного наукового дослідження, що визначає актуальність даного дослідження.

Мета дослідження - визначити основні риси дискурсу волонтерського руху як типу інституціонального дискурсу.

\section{Методи та методики дослідження Methods and Techniques of the Research}

У дослідженні використовуються емпірико-теоретичні методи дослідження, зорієнтовані на аналіз, узагальнення і опис ознак дискурсу волонтерського руху як типу інституціонального дискурсу.

\section{Результати \\ Results}

Дослідження дискурсу в руслі таких різних дисциплін, як теорія мовної комунікації (Бацевич, 2004), когнітологія (Кубрякова, 2000: 7-29), соціолінгвістика (Stubbs, 1983) соціальна психологія (Лурия, 1998), показують, що дискурс, як невід'ємна складова частина сучасного комунікативного простору, являє собою складне когнітивне соціолінгвальне явище, що включає цілий комплекс параметрів, які необхідно враховувати для його адекватного опису. Серед них - сфера діяльності, в яку залучені продуцент і реципієнт, особливості їхнього ментальності, соціальний контекст, що дає уявлення як про учасників акту комунікації, так і про процеси i умови виробництва та сприйняття повідомлення. Таке розуміння дискурсу, за Н. Арутюновою (1998: 136-137), надає можливість визначити його як мову, що сприймається як осмислена цілеспрямована соціальна дія, як компонент, який бере участь у взаємодії індивідів. 
Дискурс волонтерського руху $\epsilon$ середовищем реалізації соціальних та індивідуальних цінностей сучасного суспільства, він є його невід'ємною частиною, має вплив на формування думки у суспільстві та розгортання подій. Він реалізує певні вербальні ї невербальні моделі поведінки та актуалізує проблеми суспільства, у певному просторово-часовому континуумі. Події останніх років свідчать, що волонтери та волонтерський рух все більш впливають на зміни у суспільстві, як локальні так й глобальні й стають невід’ємною частиною суспільства. Темі дискурсу волонтерства, волонтерського руху присвячено невелика кількість робіт у сучасній лінгвістиці, зокрема вивчення лінгвосеміотичних аспектів волонтерського дискурсу, його хронотопічних аспектів у межах однієї мови (Філіпова, 2014), психології, соціології, політології (Кудринська, 2006; Тесленко, 2017; Батчер, 2015; Шлоссер, 2009), де розглядають волонтерство, як феномен громадянського суспільства та одна з ознак соціального капіталу держави, історичні аспекти розвитку волонтерства, мотивацію волонтерської діяльності тощо.

Дискурс волонтерського руху, на наш погляд, має певні ознаки інституціонального дискурсу, тобто представляє собою особливу форму мовленнєвої діяльності. Під інститутом розуміється культурно-специфічна нормативно організована конвенціональна система форм діяльності, що обумовлена суспільним поділом праці, а також призначена для задоволення особливих потреб суспільства. По суті, під інститутом розуміється будь-яка соціальна підсистема, що накладає певні (професійні, етикетні, «цехові», ритуальні і т.п.) обмеження на висловлювання/текст. При цьому будь-яке висловлювання/текст, що містить повідомлення (знання, ідеї, інформацію і т.п.) релевантне для даної соціальної підсистеми, набувають особливого значення для іiі членів i, отже, користувачі мови можуть формувати гіпотези щодо того, що буде або може бути сказано, ким, як і в якій ситуації, тобто, на думку Ван Дейка (2001), на рівні макроструктури. Для свого здійснення інституційне спілкування вимагає, по-перше, специфічного контексту, до якого воно відсилає, контексту, зрозумілого адресату; по-друге, особливого комунікативного коду, цілком або хоча 6 частково загального для адресанта i адресата; по-третє, вимагає спеціального каналу зв'язку - контакту (фізичного або психологічного) між адресантом (волонтером) та адресатом (громадянином суспільства), що дозволяє встановити i підтримувати комунікацію певного типу, яка залежить від типу інституціональних відносин між адресантом і реципієнтом ієрархічні (керівник підлеглий) або демократичні (партнери) і, відповідно, підпорядковується відносно регулярним комунікативним нормам. Комунікативні норми утворення текстів дискурсу волонтерського руху визначаються певним завданням i iнтенцією відправника повідомлення/тексту: вони мають на меті переконати реципієнта стати 
учасником дії, яка має соціальну значущість, тому й відносини між учасниками комунікації будуються партнерські та рівноправні.

\section{Висновки \\ Conclusions}

Сучасній лінгвістиці притаманна багатовекторність у розумінні поняття дискурс, що надає можливість розглядати дискурс як складне багатокомпонентне явище. Ознаками дискурсу волонтерського руху, як типу інституціонального дискурсу, є чітка ціль, певна система цінностей, перманентні учасники: агенти волонтери і волонтерські організації, пацієнти - люди/організації, що мають стати учасниками соціально значущої дії або потребують допомоги, просторово-часові ознаки. Продуктом комунікативної діяльності учасників дискурсу волонтерського руху є тексти, які репрезентують певну соціальну подію. Дослідження таких текстів $є$ перспективою подальших досліджень.

\section{Література References}

Арутюнова, Н.Д. (1998). Дискурс. Т. Николаева (Ред.), Языкознание. Москва.

Бацевич, Ф.С. (2004). Основи комунікативної лінгвістики. Київ: Академія.

Белова, А.Д.(1997). Лингвистические аспекты аргументации. (Монография). Киев: КНУ.

Кубрякова, Е.С. (2000). О понятии дискурса и дискурсивного анализа в современной лингвистике (обзор). Дискурс, речь, речевая деятельность. Функциональные и структурные аспекты. Сборник обзоров (с. 7-29). Москва.

Лурия, А.Р.(1998) Язык и сознание. Е.Д. Хомская (Ред.). Ростов-на-Дону: Изд-во «Феникс».

Медведева, Е.В. (2003). Рекламная коммуникация. Москва: УРСС.

Чернышева, Т.В. (2003) Современный публицистический дискурс (коммуникативностилистический аспект). Барнаул: Изд-во АлтГУ.

Chouliaraki, Lilie (2000) Political discourse in the news: democratizing responsibility or aestheticizing politics? Discourse \& Society, 1(3), 293-314. https://www.jstor.org/stable/42888319

Stubbs, M. (1983). Discourse Analysis: The Sociolinguistic Analysis of Natural language. Oxford. 